\title{
Anthocyanin complex exerts anti-cholangiocarcinoma activities and improves the efficacy of drug treatment in a gemcitabine-resistant cell line
}

\author{
KITTI INTUYOD ${ }^{1,2}$, AROONSRI PRIPREM ${ }^{3}$, CHAWALIT PAIROJKUL $^{2,4}$, CHARIYA HAHNVAJANAWONG ${ }^{2,5,6}$, \\ KULTHIDA VAETEEWOOTTACHARN ${ }^{2,7}$, PORNTIP PINLAOR ${ }^{2,8}$ and SOMCHAI PINLAOR SO $^{2,9}$ \\ ${ }^{1}$ Biomedical Science Program, Graduate School; ${ }^{2}$ Cholangiocarcinoma Research Institute, Faculty of Medicine; \\ ${ }^{3}$ Department of Pharmaceutical Technology, Faculty of Pharmaceutical Science; Departments of ${ }^{4}$ Pathology and \\ ${ }^{5}$ Microbiology; ${ }^{6}$ Center of Excellence for Innovation in Chemistry; ${ }^{7}$ Department of Biochemistry, Faculty of Medicine; \\ ${ }^{8}$ Centre for Research and Development in Medical Diagnostic Laboratory, Faculty of Associated Medical Sciences; \\ ${ }^{9}$ Department of Parasitology, Faculty of Medicine, Khon Kaen University, Khon Kaen 40002, Thailand
}

Received August 7, 2017; Accepted March 1, 2018

DOI: $10.3892 /$ ijo.2018.4306

\begin{abstract}
Cholangiocarcinoma (CCA) is a deleterious bile duct tumor with poor prognosis and is relatively resistant to chemotherapy. Therefore, alternative or supplementary agents with anticancer and chemosensitizing activities may be useful for the treatment of CCA. A novel anthocyanin complex (AC) nanoparticle, developed from extracts of cobs of purple waxy corn and petals of blue butterfly pea, has exhibited chemopreventive potential in vivo. In the present study, the anti-CCA activities of AC and their underlying molecular mechanisms were investigated further in vitro using a CCA cell line (KKU213). The potential use of AC as a chemosensitizer was also evaluated in a gemcitabine-resistant CCA cell line $\left(\mathrm{KKU} 214^{\mathrm{GemR}}\right)$. It was demonstrated that $\mathrm{AC}$ treatment suppressed proliferation of KKU213 CCA cells in dose- and time-dependent manners. AC treatment also induced apop-
\end{abstract}

Correspondence to: Professor Somchai Pinlaor, Department of Parasitology, Faculty of Medicine, Khon Kaen University, Khon Kaen 40002, Thailand

E-mail: psomec@kku.ac.th

Abbreviations: AC, anthocyanin complex; AEBSF, 4-(2-aminoethyl) benzenesulfonyl fluoride hydrochloride; ATF4, activating transcription factor 4; $\mathrm{BCA}$, bicinchoninic acid; CCA, cholangiocarcinoma; DMEM, Dulbecco's modified Eagle's medium; DMSO, dimethyl sulfoxide; ER, endoplasmic reticulum; FBS, fetal bovine serum; FOXM1, forkhead box protein M1; HBSS, Hank's balanced salt solution; NF- $\kappa \mathrm{B}$, nuclear factor- $\kappa \mathrm{B}$; PERK, protein kinase RNA-like endoplasmic reticulum kinase; eIF $2 \alpha$, eukaryotic initiation factor $2 \alpha$; PVDF, polyvinylidene difluoride; RIPA, radioimmunoprecipitation assay; SRB, sulforhodamine B.

Key words: anthocyanin complex, chemosensitizer, cholangiocarcinoma, forkhead box protein M1, endoplasmic reticulum stress, gemcitabine tosis and mitochondrial superoxide production, decreased clonogenicity of CCA cells, and downregulated forkhead box protein M1 (FOXM1), nuclear factor- $\kappa \mathrm{B}(\mathrm{NF}-\kappa \mathrm{B})$ and pro-survival protein B-cell lymphoma-2 (Bcl-2). The expression of endoplasmic reticulum (ER) stress-response proteins, including protein kinase RNA-like ER kinase, phosphorylated eIF2 $\alpha$, eukaryotic initiation factor $2 \alpha$ and activating transcription factor 4 , also decreased following AC treatment. It was also identified that AC treatment inhibited KKU214 ${ }^{\mathrm{GemR}}$ cell proliferation in dose- and time-dependent manners. Co-treatment of KKU214 ${ }^{\mathrm{GemR}}$ cells with low doses of AC together with gemcitabine significantly enhanced efficacy of the latter against this cell line. Therefore, it is suggested that AC treatment is cytotoxic to KKU213 cells, possibly via downregulation of FOXM1, NF- $\kappa \mathrm{B}, \mathrm{Bcl}-2$ and the ER stress response, and by induction of mitochondrial superoxide production. AC also sensitizes KKU214 ${ }^{\mathrm{GemR}}$ to gemcitabine treatment, which may have potential for overcoming drug resistance of CCA.

\section{Introduction}

Cholangiocarcinoma (CCA) is a bile-duct tumor that is rare in the majority of countries $(1,2)$, but which has a far greater incidence in the Greater Mekong sub-region of southeast Asia, particularly in northeastern Thailand, where the prevalence of the small human liver fluke Opisthorchis viverrini is high (3). O. viverrini is classified as a group I carcinogen by the International Agency for Research on Cancer (4). Infection with this fluke causes chronic inflammation, leading to periductal fibrosis and ultimately contributing to the development of CCA $(5,6)$. In northeastern Thailand, CCA is the major primary liver cancer, with its management costing US\$120 million annually (5,7). Clinical presentation is typically observed at a late stage and therefore the majority of patients with CCA cannot be cured by surgical resection $(8,9)$. Furthermore, the disease is able to develop resistance to standard chemotherapeutic drugs over time (10). Therefore, using phytochemicals with anti-inflammatory and anticancer 
activities to treat cancer or to enhance the efficacy of other chemotherapeutic drugs, may be an alternative approach for the management of CCA and help to avoid drug-resistance (11-13).

Anthocyanins are the water-soluble flavonoids responsible for the blue, purple and red colors in a number of fruits, flowers and leaves (14). Anthocyanins exhibit anti-inflammatory, anti-angiogenesis, antioxidant and anti-proliferative effects, and thus have a number of medical applications (15-18). Among these are prevention and treatment of cancer $(19,20)$. Previous studies have demonstrated that the consumption of anthocyanin-rich foods is associated with a decreased risk of chronic diseases, including cardiovascular disease, arthritis and diabetes mellitus, and development of esophageal, colon, lung and skin cancers $(17,21)$.

Cyanidin and delphinidin glycosides are the most abundant and well-studied anthocyanins with potential anticancer activity (22-24). However, a major obstacle in the use of anthocyanins is that they are unstable and prone to degradation (25). Previously, cyanidin and delphinidin were isolated from cobs of purple waxy corn (Zea mays L. var. ceritina Kulesh) and petals of blue butterfly pea (Clitoria ternatea L.) and were manipulated to form a complex with turmeric extract and other trace elements (26) to increase their stability and activity. This novel anthocyanin complex (AC) nanoparticle exhibited anti-inflammatory and anti-fibrotic effects in an $O$. viverrini-infected hamster model, establishing its potential for chemoprevention of CCA (26). However, the utility for CCA treatment has not yet been investigated.

The aim of the present study was to demonstrate the application of AC for CCA treatment. Anticancer activities of AC and the potential underlying molecular mechanisms against CCA were investigated in vitro using a CCA cell line. The effect of combined treatment of $\mathrm{AC}$ and gemcitabine against the gemcitabine-resistant CCA cell line (KKU214 ${ }^{\mathrm{GemR}}$ ) was also investigated. The results of the present study provide an insight into the promising use of $\mathrm{AC}$ phytochemical products for the treatment of CCA.

\section{Materials and methods}

Chemicals and reagents. AC was prepared as described previously (26). In brief, aqueous extracts of purple waxy corn cobs and blue butterfly pea petals were mixed with turmeric (Curcuma longa) extract (7:2:1) in the presence of $100 \mathrm{mM}$ caffeic acid and piperine (Sigma Aldrich; Merck KGaA, Darmstadt, Germany) and $2 \mathrm{mM}$ zinc sulfate (Ajax Finechem; Thermo Fisher Scientific, Inc., Waltham, MA, USA). Thereafter, the mixture was cooled and dried to yield of AC. Only one batch of AC was used throughout the present study to avoid batch-to-batch variation. Dulbecco's modified Eagle's medium (DMEM), penicillin/streptomycin, trypsin-EDTA and fetal bovine serum (FBS) were purchased from Gibco; Thermo Fisher Scientific, Inc. 4-(2-Aminoethyl) benzenesulfonyl fluoride hydrochloride (AEBSF), dimethyl sulfoxide (DMSO), sulforhodamine B (SRB) and the broad-spectrum caspase inhibitor quinolone-Val-Aspdifluorophenoxymethyl ketone (Q-VD-OPh) were purchased from Sigma-Aldrich; Merck KGaA. Rabbit anti-protein kinase RNA-like endoplasmic reticulum (ER) kinase (PERK; cat. no. 5683), anti-p65 (cat. no. 8242), anti-activating transcription factor 4 (ATF4; cat. no. 11815), anti-phosphorylated eukaryotic initiation factor $2 \alpha$ (p-eIF2 $\alpha$; cat. no. 3398) ( $\left.\operatorname{Ser}^{51}\right)$, anti-eIF2 $\alpha$ (cat. no. 9722), anti-poly(ADP-ribose) polymerase (PARP; cat. no. 9542), anti-B-cell lymphoma-2 (Bcl-2; cat. no. 2872), anticaspase-3 (cat. no. 9662) and anti- $\beta$-tubulin (cat. no. 2128) and radioimmunoprecipitation assay (RIPA) buffer were purchased from Cell Signaling Technology, Inc. (Danvers, MA, USA). Rabbit anti-forkhead box M1 (FOXM1; cat. no. sc-502) (C-20) was obtained from Santa Cruz Biotechnology, Inc. (Dallas, TX, USA). Horseradish peroxidase (HRP)-conjugated goat anti-rabbit IgG (cat. no. 111-035-003) secondary antibody was purchased from Jackson ImmunoResearch, Inc. (West Grove, PA, USA). A dead-cell apoptosis kit [Annexin V/propidium iodide (PI)], Pierce ${ }^{\mathrm{TM}}$ bicinchoninic acid (BCA) protein assay kit, Hank's balanced salt solution (HBSS) and MitoSOX ${ }^{\mathrm{TM}}$ Red mitochondrial superoxide indicator were obtained from Thermo Fisher Scientific, Inc. ECL ${ }^{\mathrm{TM}}$ Prime western blotting detection reagent and polyvinylidene difluoride (PVDF) membrane were obtained from GE Healthcare (Chicago, IL, USA).

Human CCA cell lines. The KKU213 CCA cell line was established from Thai CCA patients as described previously (27). The gemcitabine-resistant CCA cell line KKU214 ${ }^{\mathrm{GemR}}$ was established previously by exposure to stepwise increases in the concentration of gemcitabine as described previously (28). It should be noted that the parental line of KKU214 ${ }^{\mathrm{GemR}}$ cells appears to be a KKU213 cell derivative (web.expasy.org/cellosaurus/CVCL_M264). However, due to the fact that KKU214 ${ }^{\mathrm{GemR}}$ cells were induced to be a gemcitabine-resistant CCA cell line, it would not have any bearing on the results of the present study. The cell lines were maintained in DMEM supplemented with $10 \% \mathrm{FBS}$, $100 \mathrm{U} / \mathrm{ml}$ penicillin and $100 \mu \mathrm{g} / \mathrm{ml}$ streptomycin at $37^{\circ} \mathrm{C}$ in a humidified incubator containing $10 \% \mathrm{CO}_{2}$. KKU214 ${ }^{\mathrm{GemR}}$ cells were cultured in the presence of gemcitabine to maintain its resistant phenotype, but were cultured in a drug-free medium for one passage prior to performing experiments.

Assessment of half-maximal inhibitory concentration $\left(I C_{50}\right)$ of $A C$. The $\mathrm{IC}_{50}$ was assessed using the SRB assay. For instance, KKU213 cells were seeded at 2,000 cells/well in flat-bottomed 96-well plates (Corning Inc., Corning, NY, USA). The following day, the cells were incubated with either DMSO (diluent control) or various concentrations of AC $(100-800 \mu \mathrm{g} / \mathrm{ml})$ dissolved in DMSO for 12, 24, 36 and $48 \mathrm{~h}$ at $37^{\circ} \mathrm{C}$ in a humidified incubator containing $10 \% \mathrm{CO}_{2}$. Cells were fixed with ice-cold $40 \%$ trichloroacetic acid at $4^{\circ} \mathrm{C}$ for $1 \mathrm{~h}$. Following washing three times with running tap water, $0.4 \%(\mathrm{w} / \mathrm{v}) \mathrm{SRB}$ solution in $1 \%$ acetic acid was added and incubated further for $1 \mathrm{~h}$ at room temperature. Excess SRB solution was removed by washing with $1 \%$ acetic acid and SRB was dissolved by adding $10 \mathrm{mM}$ Tris buffer. Absorbance at $492 \mathrm{~nm}$ was determined using an ELISA plate reader (Tecan Group Ltd., Männedorf, Switzerland). The absorbance at $492 \mathrm{~nm}$ of DMSO-treated cells was used as control. For KKU214 ${ }^{\mathrm{GemR}}$ cells, the same procedure was performed, but the cells were treated with either single agent $(300 \mu \mathrm{g} / \mathrm{ml} \mathrm{AC} ; 20$ or $40 \mu \mathrm{M}$ gemcitabine) or a combination of $\mathrm{AC}(300 \mu \mathrm{g} / \mathrm{ml})$ and gemcitabine (20 or $40 \mu \mathrm{M}$ ) for 24,48 and $72 \mathrm{~h}$. 
A

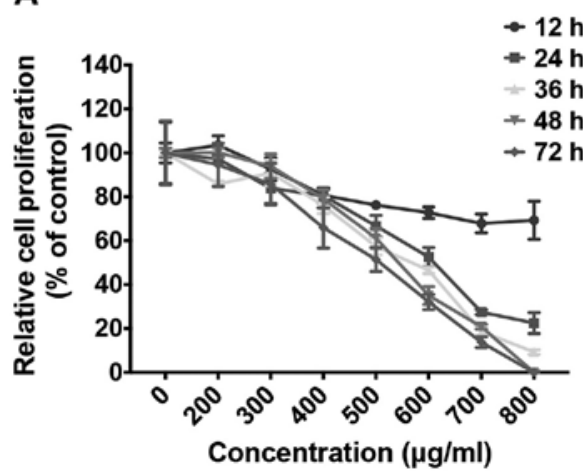

B

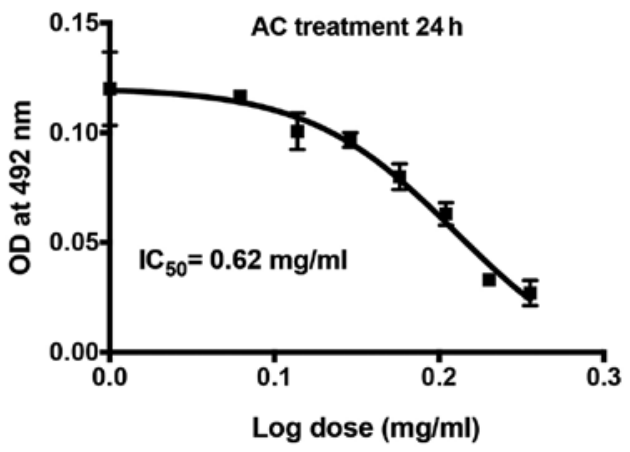

Figure 1. AC inhibits proliferation of the KKU213 CCA cell line. (A) KKU213 CCA cells were treated with different concentrations of AC for the indicated time periods. The percentage of cell proliferation was determined using the SRB assay compared with its control treatment (dimethyl sulfoxide). (B) $\mathrm{IC}_{50}$ of $\mathrm{AC}$ on KKU213 cells at $24 \mathrm{~h}$ post-treatment was calculated using a dose-response curve analysis. Experiments were carried out in triplicate. AC, anthocyanin complex; CCA, cholangiocarcinoma; SRB, sulforhodamine B; $\mathrm{IC}_{50}$, half-maximal inhibitory concentration; OD, optical density.

Assessment of cellular apoptosis. Cellular apoptosis was determined by Annexin V/PI staining according to the manufacturer's protocol. In brief, following trypsinization and washing with sterile PBS, $\sim 10^{6} \mathrm{KKU} 213$ cells were resuspended in $1 \mathrm{X}$ binding buffer. Annexin V/PI solution was added prior to incubation at room temperature in the dark for $15 \mathrm{~min}$. Stained cells were detected using a BD FACSCanto II flow cytometer and analyzed using BD FACSDiva software (version 6.1.3) (both from BD Biosciences, San Jose, CA, USA).

Plasmid transfection. The pCMV4-p65 plasmid was a gift from Professor Warner Greene, Gladstone Institute of Virology and Immunology, San Francisco, CA, USA (Addgene plasmid \#21966). In total $2 \times 10^{6} \mathrm{KKU} 213$ cells were seeded into $10-\mathrm{cm}$ cell culture dishes for $24 \mathrm{~h}$, prior to transfection with pCMV4-p65 plasmid using X-tremeGENE HP (Roche Diagnostics, Basel, Switzerland), according to the manufacturer's protocol. Cells were then harvested at $24 \mathrm{~h}$ post-transfection for further experiments.

Clonogenic assay. CCA cells were seeded into 6-well plates at a density of 1,000 cells/well overnight prior to drug treatment. Cells were treated with different concentrations of $\mathrm{AC}(100-800 \mu \mathrm{g} / \mathrm{ml})$ and incubated for $48 \mathrm{~h}$ at $37^{\circ} \mathrm{C}$ in a humidified incubator containing $10 \% \mathrm{CO}_{2}$. In the case of KKU214 ${ }^{\mathrm{GemR}}$ cells, cells were treated with either a single agent $(300 \mu \mathrm{g} / \mathrm{ml} \mathrm{AC} ; 20$ or $40 \mu \mathrm{M}$ gemcitabine) or a combination of $\mathrm{AC}(300 \mu \mathrm{g} / \mathrm{ml})$ and gemcitabine $(20$ or $40 \mu \mathrm{M})$. The culture medium was changed every 2 days and cells were cultured for a further 14 days. Finally, cells were fixed with $4 \%$ paraformaldehyde and stained with $0.5 \%$ crystal violet. Stained cells were dissolved with $33 \%$ acetic acid and absorbance at $620 \mathrm{~nm}$ was measured using an ELISA reader (Tecan Group Ltd.).

Measurement of mitochondrial superoxide production. Mitochondrial superoxide production was determined using MitoSOX Red mitochondrial superoxide indicator, according to the manufacturer's protocol. In brief, CCA cells were trypsinized, washed once and resuspended in HBSS with $\mathrm{Ca}^{2+} / \mathrm{Mg}^{2+}$. Subsequently, $4 \mu \mathrm{M}$ MitoSOX Red solution was added and the mixture was incubated at $37^{\circ} \mathrm{C}$ for $30 \mathrm{~min}$ in the dark. CCA cells were centrifuged at $600 \mathrm{x} \mathrm{g}$ for $5 \mathrm{~min}$ at room temperature and washed with $1 \mathrm{ml} \mathrm{HBSS} / \mathrm{Ca}^{2+} / \mathrm{Mg}^{2+}$. Finally, CCA cells were resuspended in $\mathrm{HBSS} / \mathrm{Ca}^{2+} / \mathrm{Mg}^{2+}$ and the fluorescence intensity at $575 \mathrm{~nm}$ was measured using a flow cytometer (BD Biosciences).

Western blot analysis. Protein was extracted from CCA cells using RIPA buffer $(50 \mathrm{mM}$ Tris/ $\mathrm{HCl}, 150 \mathrm{mM} \mathrm{NaCl}$, $1 \%$ Nonidet P-40, $0.5 \%$ sodium deoxycholate, $0.1 \%$ SDS and $1 \mathrm{mM}$ AEBSF) and the protein concentration was determined using the BCA assay. Subsequently, $20 \mu \mathrm{g}$ protein was separated by SDS-PAGE (7 or 12\% gels) and then transferred onto a PVDF membrane. Following blocking with $5 \%$ bovine serum albumin in Tris-buffered saline containing $0.05 \%$ Tween-20, membranes were incubated with primary antibodies against PERK, p65, ATF4, p-eIF2 $\alpha\left(\operatorname{Ser}^{51}\right)$, eIF2 $\alpha$, PARP, caspase-3, Bcl-2 and $\beta$-tubulin (all 1:1,000) overnight at $4^{\circ} \mathrm{C}$. Following washing, membranes were incubated with secondary antibody $(1: 3,000)$ and the chemiluminescent reaction was developed using ECL ${ }^{\mathrm{TM}}$ Prime blotting detection reagent. Immunoreactivity bands were captured using the ImageQuant ${ }^{\mathrm{TM}}$ LAS4000 mini imager (GE Healthcare).

Statistical analysis. Data are expressed as the mean \pm standard deviation. Student's t-test and analysis of variance and Tukey's test were performed to determine differences among experimental groups using SPSS (version 13.0; SPSS, Inc., Chicago, IL, USA). $\mathrm{P}<0.05$ was considered to indicate a statistically significant difference. Non-linear regression analysis was performed to determine the $\mathrm{IC}_{50}$ values using GraphPad Prism (version 6; GraphPad Software, Inc., La Jolla, CA, USA).

\section{Results}

AC treatment inhibits proliferation and induces caspaseindependent apoptosis of the CCA cell line. Inhibition of tumor growth and induction of cellular apoptosis are important modes of action of the majority of phytochemical agents. To determine whether AC exerts proliferation-inhibitory effects on CCA cells, and to determine relevant $\mathrm{IC}_{50}$ values, KKU213 cells were treated with various concentrations of AC. The SRB assay revealed that $\mathrm{AC}$ inhibited cell proliferation in this cell 


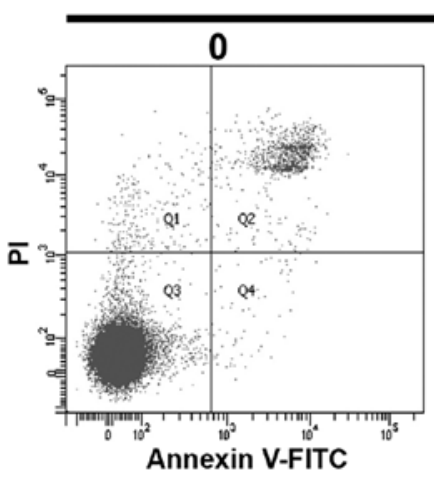

B

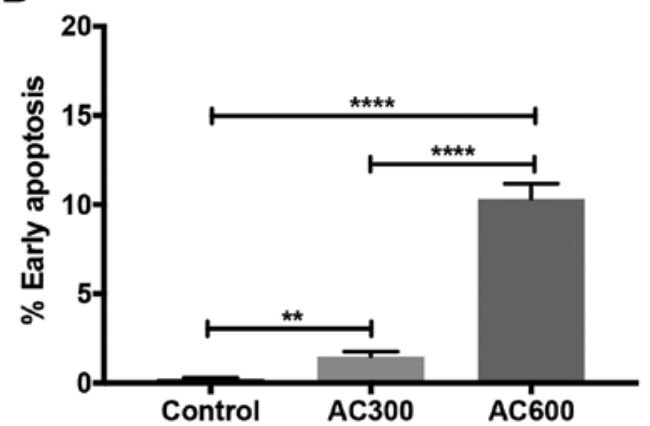

300

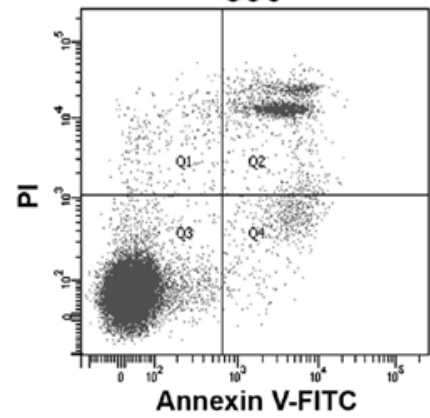

C

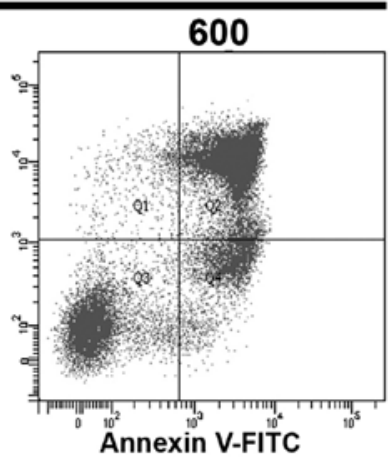

Annexin V-FITC

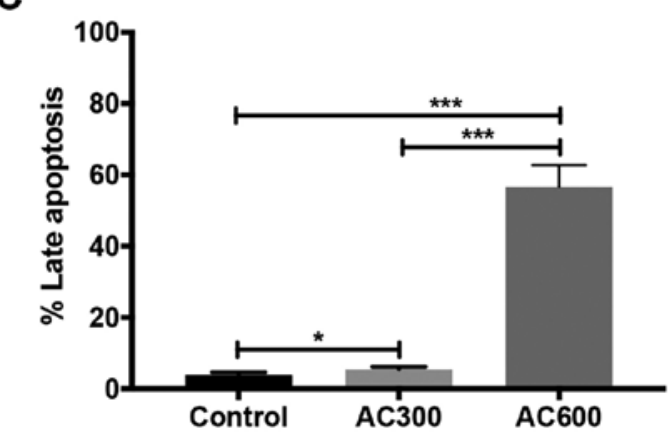

Figure 2. AC treatment induces apoptosis of CCA cells. (A) KKU213 cells were treated with AC at the indicated doses for 24 h. Apoptotic cells were stained with Annexin V-FITC/PI solution and analyzed by flow cytometry. Dimethyl sulfoxide at a final concentration of $0.1 \%$ was used as diluent control $(0)$. (B) Percentages of early apoptosis and (C) late apoptosis of AC-treated KKU213 cells were calculated from three independent experiments. $\mathrm{P}<0.05$, ${ }^{* *} \mathrm{P}<0.01$, ${ }^{* * *} \mathrm{P}<0.001$ and ${ }^{* * * *} \mathrm{P}<0.0001$. AC, anthocyanin complex; FITC, fluorescein isothiocyanate; PI, propidium iodide.

line in a dose- and time-dependent manner (Fig. 1A). The proliferation of KKU213 cells was completely inhibited by treatment with $800 \mu \mathrm{g} / \mathrm{ml} \mathrm{AC}$ after $48 \mathrm{~h}$. Non-linear regression analysis identified that the $\mathrm{IC}_{50}$ value of $\mathrm{AC}$ for KKU213 was $620 \mu \mathrm{g} / \mathrm{ml}$ (Fig. 1B).

It was subsequently investigated whether suppression of CCA cell proliferation by AC treatment is associated with induction of apoptosis. KKU213 cells were treated with 300 or $600 \mu \mathrm{g} / \mathrm{ml} \mathrm{AC}$ for $24 \mathrm{~h}$, and cellular apoptosis was investigated using flow cytometry (Fig. 2A). The results revealed that early $(1.50 \pm 0.27 \%$ for $\mathrm{AC} 300$ and $10.33 \pm 0.83 \%$ for AC600) (Fig. 2B) and late $(5.50 \pm 0.66 \%$ for AC300 and $56.70 \pm 6.05 \%$ for AC600) (Fig. 2C) apoptosis was significantly induced dose-dependently in AC-treated groups compared with the control group. These results indicated that $\mathrm{AC}$ exhibited cytotoxicity against CCA cells through the induction of cellular apoptosis. Levels of cleaved caspase-3, a protein marker for cellular apoptosis, was also assayed using western blotting. Cleaved caspase-3 was not observed in AC-treated KKU213 cells, but was detected in a gemcitabinetreated group (Fig. 3A). In addition, a pan-caspase inhibitor (Q-VD-OPh) was combined with AC treatment to test whether cell death was due to a caspase-independent pathway. A clonogenic assay demonstrated that treatment with 2 and $10 \mu \mathrm{M}$ Q-VD-OPh, identified to prevent caspase activation (29), did not affect cell viability of the KKU213 cells (Fig. 3C). Notably, Q-VD-OPh treatment was not able to prevent cell death when combined with AC treatment (Fig. 3D and E), indicating that caspase-independent cell death was occurring in AC-treated CCA cells.
AC treatment inhibits colony formation of the CCA cell line. The clonogenic assay is the method of choice to determine cell reproductive viability (ability of cells to produce progeny or ability of a single cell to form a colony) following treatment with radiation or a cytotoxic agent $(30,31)$. This approach was employed to determine the cytotoxic effects of AC treatment on a CCA cell line (Fig. 4A). Consistent with the results of the SRB assay, the presence of AC significantly inhibited KKU213 colony formation in a dose-dependent manner compared with the control group $(\mathrm{P}<0.0001)$ (Fig. 4B). This result indicated that the $\mathrm{AC}$-mediated decrease in reproductive viability is one of the underlying molecular mechanisms of AC against CCA.

AC treatment induces mitochondrial superoxide production partly via suppression of $\mathrm{Bcl}-2$ expression. Induction of superoxide production in mitochondria is an important event in the induction of apoptosis (32). To investigate whether induction of mitochondrial superoxide production is involved in AC-induced apoptosis of CCA cells, KKU213 cells were treated with AC, and levels of mitochondria-specific superoxide were determined using flow cytometry. Minimal superoxide production was detected in the control group; however, production was slightly increased in KKU213 cells treated with $300 \mu \mathrm{g} / \mathrm{ml} \mathrm{AC} \mathrm{(Fig.} \mathrm{5).} \mathrm{Treatment} \mathrm{with} 600$ $\mu \mathrm{g} / \mathrm{ml}$ AC significantly induced superoxide production in the mitochondria of KKU213 cells relative to the control group $(\mathrm{P}<0.001)$ (Fig. 5).

Since superoxide production may be inhibited by the antiapoptotic Bcl-2 protein (32), the expression of Bcl-2 protein was investigated further in KKU213 CCA cells. Western blot 
A

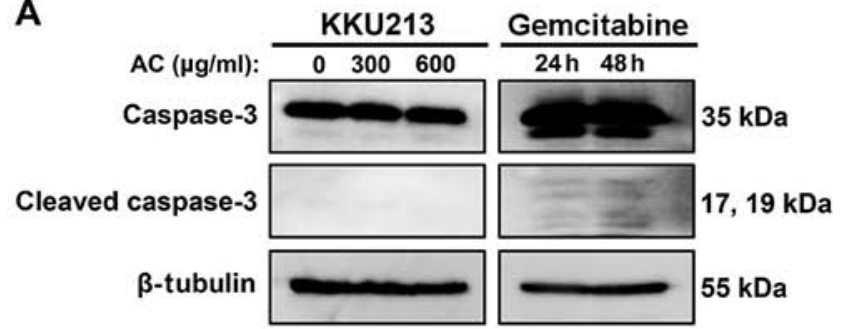

B

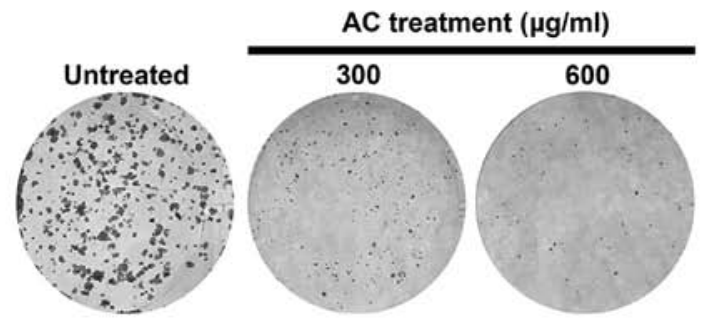

C

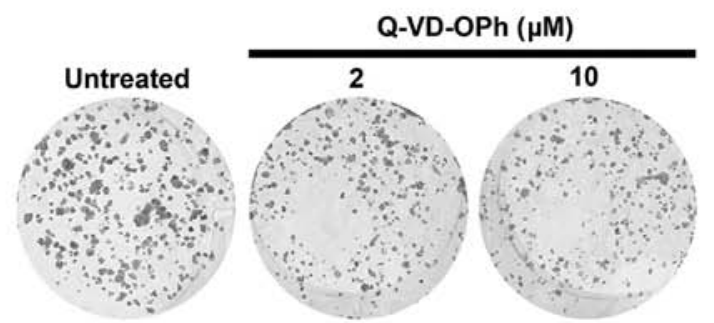

D

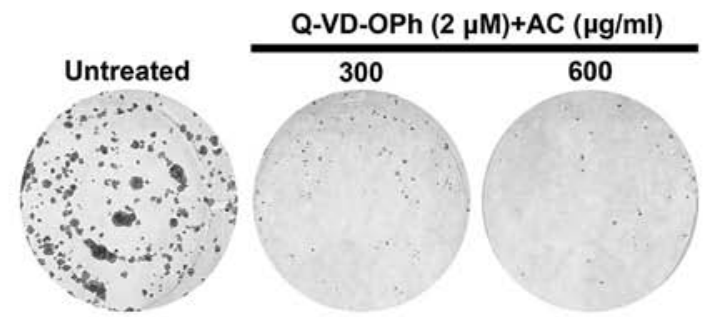

E

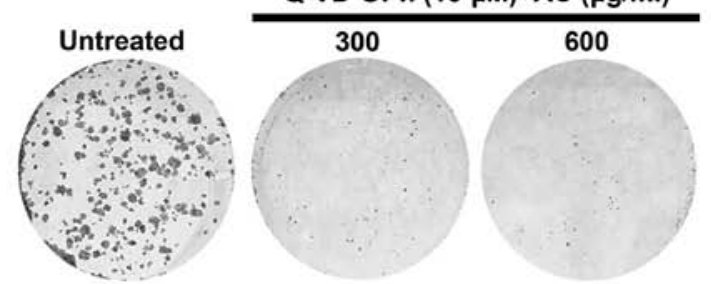

Figure 3. Pan-caspase inhibitor Q-VD-OPh does not protect KKU213 cells from AC-induced cell death. (A) Western blot analysis was performed to determine the expression of caspase- 3 and its cleaved form in AC-treated KKU213 cells compared with cells treated with gemcitabine. $\beta$-tubulin was used as a loading control. The viability of KKU213 cells following (B) AC treatment, (C) Q-VD-OPh treatment and the combination of (D) $2 \mu \mathrm{M}$ and (E) $10 \mu \mathrm{M}$ Q-VD-OPh with AC treatment was determined using a clonogenic assay. Q-VD-OPh, quinolone-Val-Asp-difluorophenoxymethyl ketone; $\mathrm{AC}$, anthocyanin complex.

analysis revealed that the expression of $\mathrm{Bcl}-2$ protein mirrored superoxide production. Expression of $\mathrm{Bcl}-2$ protein decreased in the AC-treated group, particularly when $600 \mu \mathrm{g} / \mathrm{ml} \mathrm{AC}$ was used, relative to the DMSO-treated control (Fig. 6). These results indicated that $\mathrm{AC}$ induced superoxide production-mediated apoptosis partly via the inhibition of $\mathrm{Bcl}-2$ protein expression.

AC treatment targets pro-survival and endoplasmic reticulum stress (ER stress) response of the CCA cell line. FOXM1 and
$\mathrm{NF}-\kappa \mathrm{B}$ are well-known oncogenic proteins involved in the survival of cancer cells $(33,34)$. The expression of these proteins was determined in the CCA cell line following treatment with $\mathrm{AC}$ for $24 \mathrm{~h}$. Western blot analysis revealed that expression of FOXM1 and the p65 subunit of NF- $\mathrm{\kappa B}$ decreased in a dosedependent manner in KKU213 cells treated with AC (Fig. 6). Notably, expression of these proteins was almost completely inhibited in KKU213 cells treated with $600 \mu \mathrm{g} / \mathrm{ml}$ AC compared with the DMSO-treated control (Fig. 6). Additionally, KKU213 cells were transfected with p65 plasmid DNA and the influence of p65 induction on AC treatment of KKU213 cells was determined using a clonogenic assay. The p65 subunit of NF- $\mathrm{KB}$ was successfully induced in KKU213 as identified using western blot analysis (Fig. 7A). However, the clonogenic assay revealed that $\mathrm{p} 65$ overexpression did not affect the viability of KKU213 cells compared with non-transfected and mock-transfected controls (Fig. 7B and C). This implies that $\mathrm{AC}$ is a potent inducer of apoptosis against CCA cells, and that induction of a pro-survival transcription factor was not able to protect CCA cells from cell death following AC treatment. A previous study has identified that AC treatment dramatically induced mitochondrial superoxide production; excessive superoxide production may cause protein misfolding and ultimately induce ER stress (35). Therefore, the expression of proteins in the PERK/eIF2 $\alpha / \mathrm{ATF} 4$ axis, which is an important ER stress-response pathway, was investigated. Western blot analysis revealed that expression of PERK, p-eIF2 $\alpha\left(\mathrm{Ser}^{51}\right)$ and ATF4 in KKU213 cells decreased following AC treatment (Fig. 6). Notably, total eIF2 $\alpha$ expression was not affected by AC treatment, suggesting that AC suppresses phosphorylation of the eIF $2 \alpha$ protein. In addition to FOXM1, p65 and the PERK/eIF2 $\alpha /$ ATF4 axis, it was identified that PARP expression was also suppressed by AC treatment, particularly at the highest dose used (Fig. 6).

$A C$ treatment increases gemcitabine sensitivity of the gemcitabine-resistant KKU214 ${ }^{\mathrm{GemR}} \mathrm{CCA}$ cell line. Resistance to chemotherapeutic treatment is an important obstacle for the treatment of various types of cancer, including CCA (36). Therefore, whether co-treatment with $\mathrm{AC}$ was able to enhance the effect of gemcitabine was investigated. The SRB assay revealed that the $\mathrm{IC}_{50}$ of gemcitabine against the KKU214 ${ }^{\mathrm{GemR}} \mathrm{CCA}$ cell line was $32.11 \mu \mathrm{M}$ at $72 \mathrm{~h}$, whereas the $\mathrm{IC}_{50}$ of gemcitabine against the parental KKU214 cell line was $0.40 \mu \mathrm{M}$ at $72 \mathrm{~h}$ (data not shown), agreeing with a previous study (28). Treatment of KKU214 GemR cells with AC inhibited cell proliferation in a dose- and time-dependent manner (Fig. 8A). For gemcitabine treatment alone, KKU214 ${ }^{\mathrm{GemR}}$ cell proliferation was markedly inhibited by treatment with $40 \mu \mathrm{M}$ for $72 \mathrm{~h}$ (Fig. 8B). AC at a dose of $300 \mu \mathrm{g} / \mathrm{ml}$, which did not exert a proliferation-inhibitory effect on KKU214 ${ }^{\mathrm{GemR}}$ cells, was selected for co-treatment with 20 or $40 \mu \mathrm{M}$ gemcitabine. As expected, the two combinations significantly enhanced gemcitabine-mediated proliferation inhibition compared with treatments with single agents $(\mathrm{P}<0.01$ for $20 \mu \mathrm{M}$ gemcitabine vs. $300 \mu \mathrm{g} / \mathrm{ml} \mathrm{AC}+20 \mu \mathrm{M}$ gemcitabine; $\mathrm{P}<0.001$ for $40 \mu \mathrm{M}$ gemcitabine vs. $300 \mu \mathrm{g} / \mathrm{ml} \mathrm{AC}+40 \mu \mathrm{M}$ gemcitabine) (Fig. 8C). Furthermore, the clonogenic assay also identified a significant enhancement of gemcitabine treatment when co-treated with AC $(\mathrm{P}<0.05)($ Fig. 8D). Annexin V/PI 

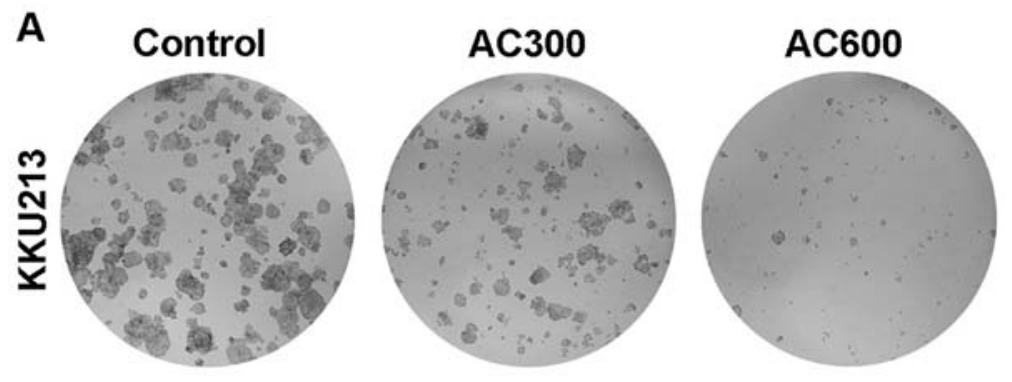

B

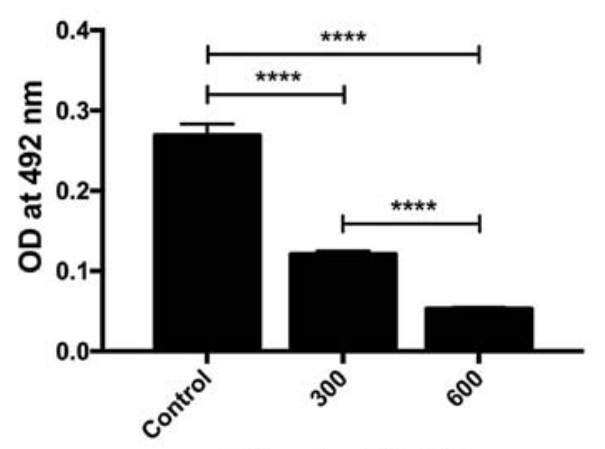

AC treatment $(\mu \mathrm{g} / \mathrm{ml})$

Figure 4. AC treatment decreases colony formation of CCA cells. (A) KKU213 cells were seeded in 6-well plates at a density of 1,000 cells/well and cultured with AC or dimethyl sulfoxide (control) for $48 \mathrm{~h}$. At day 14, colony formation was visualized by crystal violet staining and images were captured using a digital camera. (B) Relative difference of colony formation of CCA cells was investigated by dissolving stained colonies with $33 \%$ acetic acid and determining the OD at $620 \mathrm{~nm} .{ }^{* * * *} \mathrm{P}<0.0001$. AC, anthocyanin complex; CCA, cholangiocarcinoma; OD, optical density.

A AC treatment $(\mu \mathrm{g} / \mathrm{ml})$
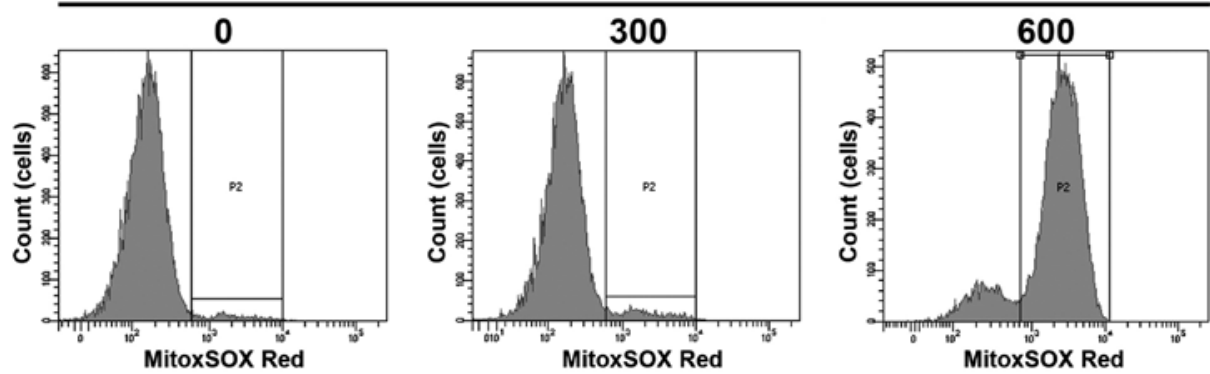

B

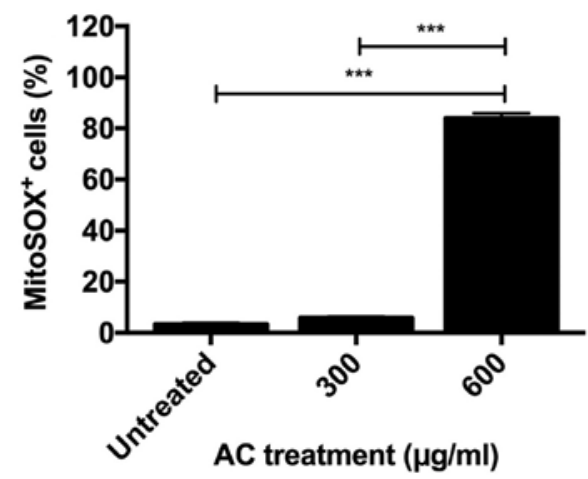

Figure 5. Mitochondrial superoxide production is markedly induced by AC treatment. (A) Mitochondrial superoxide production following AC treatment of KKU213 cells was determined using MitoSOX Red coupled with flow cytometry. A peak at P2 indicates superoxide production from mitochondria. Cells treated with dimethyl sulfoxide ( $0.1 \%)$ were used as diluent control. Experiments were performed in triplicate. (B) The percentage of mitochondrial superoxide production was calculated and plotted relative to the number of cells measured. ${ }^{* * *} \mathrm{P}<0.001$. AC, anthocyanin complex.

staining coupled with flow cytometry was used to detect apoptotic cells following combination treatment of KKU214 cells. Administration of $\mathrm{AC}(300 \mu \mathrm{g} / \mathrm{ml})$ and gemcitabine
$(40 \mu \mathrm{M})$ significantly induced early apoptosis of these cells compared with single treatments and the control group $(\mathrm{P}<0.0001)$ (Fig. 9). These results indicated that AC treatment 


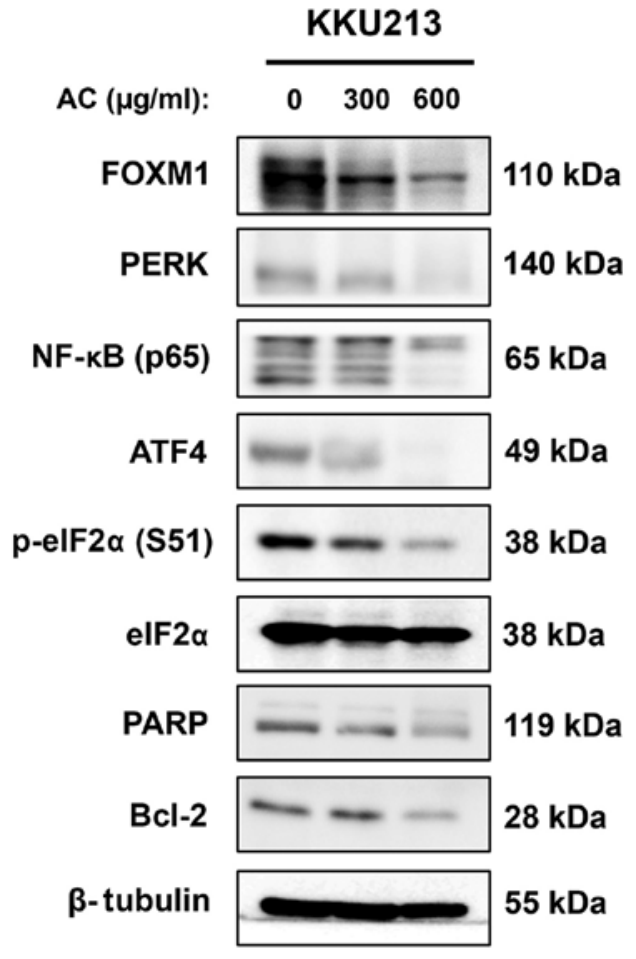

Figure 6. AC treatment downregulates the expression of a number of survivalassociated proteins and endoplasmic reticulum stress proteins. KKU213 cells were treated with $\mathrm{AC}$ for $24 \mathrm{~h}$ prior to western blotting. $\beta$-tubulin expression was used as loading control. AC, anthocyanin complex; FOXM1, forkhead box M1; PERK, protein kinase RNA-like endoplasmic reticulum kinase; $\mathrm{NF}-\kappa \mathrm{B}$, nuclear factor- $\kappa \mathrm{B}$; ATF4, activating transcription factor 4 ; eIF2 $\alpha$, eukaryotic initiation factor $2 \alpha$; p-eIF $2 \alpha$, phosphorylated eIF $2 \alpha$; PARP, poly(ADP-ribose) polymerase; Bcl-2, B-cell lymphoma-2.

significantly enhanced the efficacy of gemcitabine against the gemcitabine-resistant KKU214 ${ }^{\mathrm{GemR}}$ cell line.

\section{Discussion}

Several previous studies have demonstrated that anthocyanins exert anticancer activity against various types of cancer, including HCC, melanoma, colon cancer, lung cancer and breast cancer (37-39). In our previous study, we developed a novel AC, which primarily consisted of extracts of purple corn cobs, blue butterfly peas and turmeric (26). The combination of these exhibited increased antioxidant activity and increased thermal stability compared with that of individual extracts (26). In the present study, to the best of our knowledge, we have identified, for the first time, anti-CCA activity of $\mathrm{AC}$, which exhibited cytotoxicity against a CCA cell line through the suppression of cell proliferation and induction of caspase-independent apoptosis probably via increased mitochondrial superoxide production. Furthermore, AC also suppressed the expression of a number of oncogenic proteins that have previously been reported to be upregulated in CCA, including FOXM1, NF- $\kappa \mathrm{B}$ and ER stress-response proteins. The potential underlying molecular mechanisms of AC treatment on CCA cells are summarized in Fig. 10. AC was able to potentiate gemcitabine treatment against the gemcitabineresistant KKU214 ${ }^{\mathrm{GemR}}$ cell line. We therefore hypothesize that $\mathrm{AC}$ has a potential function as an alternative or supplementary treatment for CCA.
A

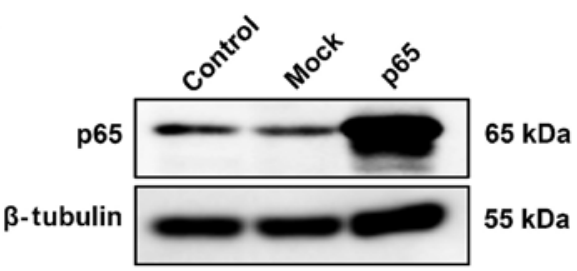

B
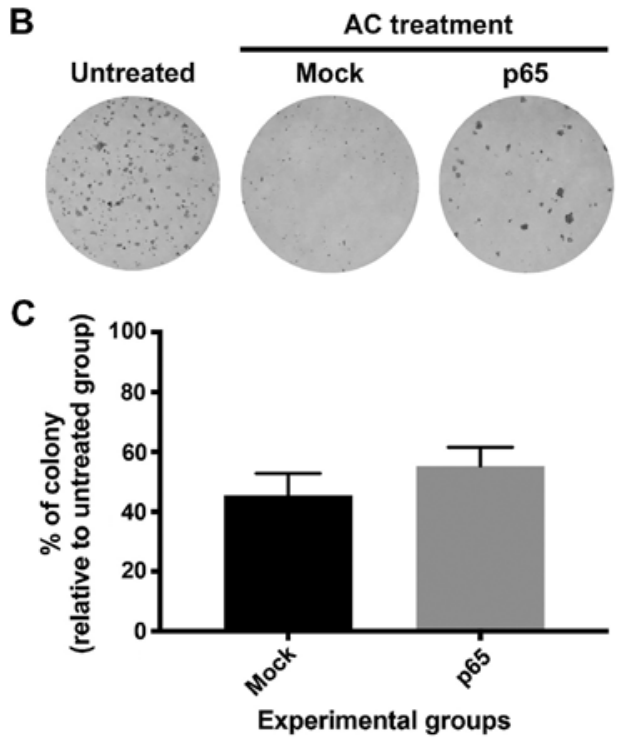

Figure 7. Overexpression of $\mathrm{p} 65 \mathrm{NF}-\kappa \mathrm{B}$ does not affect the anticancer activity of $\mathrm{AC}$ in the KKU213 cell line. Expression of p $65 \mathrm{NF}-\kappa \mathrm{B}$ was induced in KKU213 cells using a combination of pCMV4-p65 plasmid DNA and X-tremeGENE HP. (A) The expression of p65 in p65-transfected cells was detected by western blot analysis compared with control and mock transfections. (B) The effect of p65 overexpression on AC treatment was determined using a clonogenic assay. (C) Relative difference of colony formation of KKU213 cell line was investigated by dissolving stained colonies with $33 \%$ acetic acid and determining the optical density at $620 \mathrm{~nm}$. NF- $\kappa \mathrm{B}$, nuclear factor- $\kappa \mathrm{B} ; \mathrm{AC}$, anthocyanin complex.

cDNA analysis of $O$. viverrini-associated CCA clinical samples revealed that FOXM1 was highly expressed, being the second most abundant gene in these samples (40). FOXM1 has been implicated primarily in cell proliferation and survival, as well as in cancer progression (34). In the present study, suppression of cell proliferation and induction of cellular apoptosis following AC treatment were observed alongside downregulation of FOXM1 expression. These results suggest that suppression of FOXM1 is, in part, the mode of action of AC against CCA. To the best of our knowledge, the present study is the first to identify the effects of cyanidin and delphinidin on FOXM1 expression. However, a previous study demonstrated that curcumin, an important bioactive compound in turmeric extract, was able to suppress FOXM1 (41). Therefore, suppression of FOXM1 using AC treatment is potentially mediated by either anthocyanin(s) (cyanidin and/or delphinidin) or turmeric extract or both. In addition to FOXM1, western blot analysis also demonstrated the downregulation of $\mathrm{NF}-\kappa \mathrm{B}$ in AC-treated CCA cells. NF- $\kappa \mathrm{B}$ is a well-known transcription factor associated with inflammation and cancer (42-44). A previous study has identified that $\mathrm{NF}-\kappa \mathrm{B}$, particularly its p65 subunit, was overexpressed in $O$. viverrini-associated CCA tumor tissues. Furthermore, treatment with dehydroxymethylepoxyquinomicin inhibited CCA cell proliferation and induced apoptosis 
A

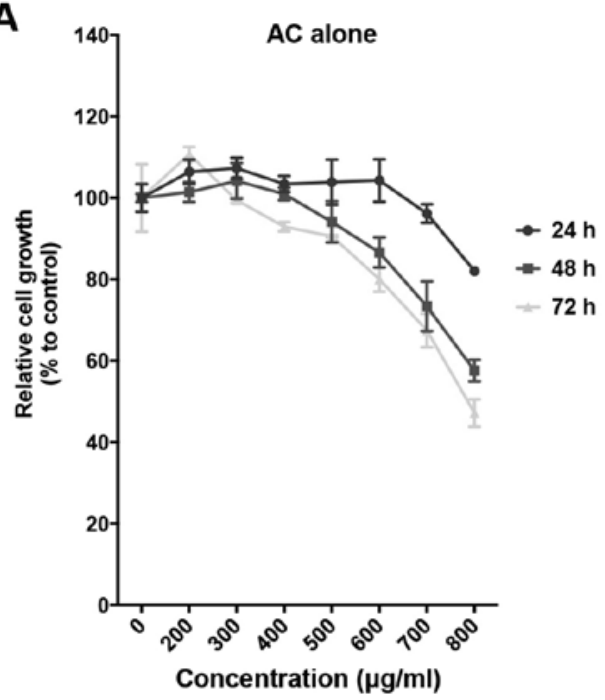

C

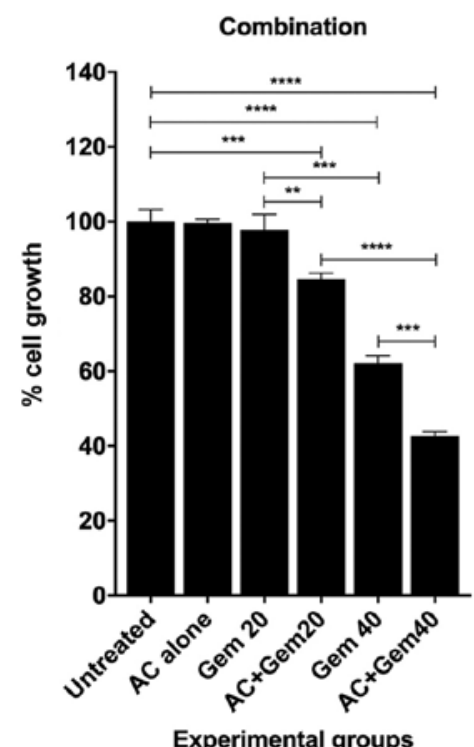

B

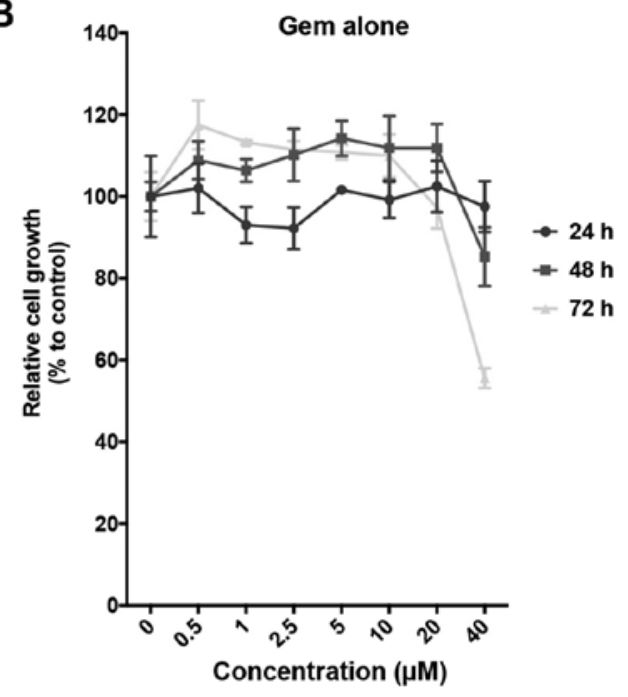

D
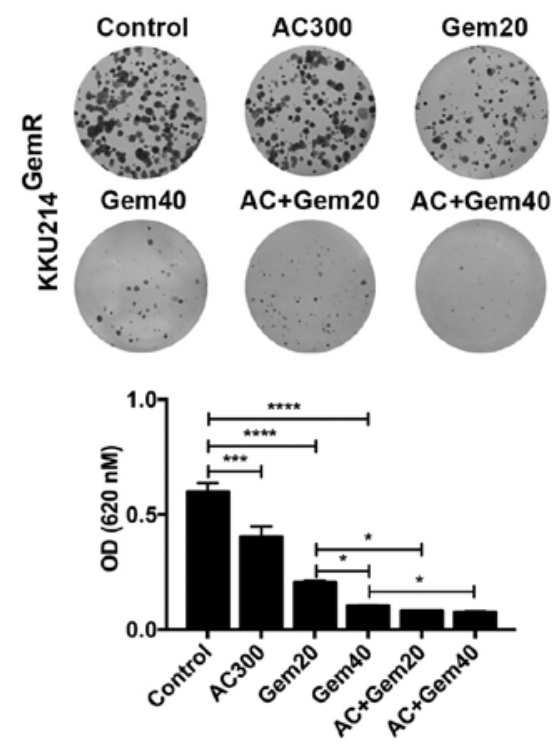

Figure 8. AC treatment sensitizes the KKU214 ${ }^{\mathrm{GemR}}$ cell line to gemcitabine treatment. KKU214 ${ }^{\mathrm{GemR}}$ cells were seeded in 96-well plates and treated with either (A) $\mathrm{AC}$ alone or (B) gemcitabine alone at indicated times. (C) Cells were treated with either the single agent (AC or gemcitabine) or a combination of AC $(300 \mu \mathrm{g} / \mathrm{ml})$ and gemcitabine $(20$ or $40 \mu \mathrm{M})$ for $72 \mathrm{~h}$. The percentage of cell proliferation (relative to control) was determined using the SRB assay. Inhibition of cell proliferation was observed in the combination treatment compared with treatment with either agent alone. (D) Effect of combined treatment on colony formation of KKU214 ${ }^{\mathrm{GemR}}$ cells was also determined using the clonogenic assay. The relative difference in colony formation of KKU214 ${ }^{\mathrm{GemR}}$ cells was investigated by dissolving stained colonies with $33 \%$ acetic acid and absorbance at the $\mathrm{OD}$ at $620 \mathrm{~nm}$ was determined using an ELISA reader. ${ }^{*} \mathrm{P}<0.05,{ }^{* *} \mathrm{P}<0.01$, ${ }^{* * * *} \mathrm{P}<0.001$ and ${ }^{* * * * *} \mathrm{P}<0.0001$. AC, anthocyanin complex; Gem, gemcitabine; OD, optical density.

in KKU213 cells via the suppression of NF- $\mathrm{BB}$ and $\mathrm{Bcl}-2$ proteins (45). The results of the present study are in general agreement with this previous study, demonstrating that the p65 subunit of NF- $\mathrm{kB}$ and Bcl-2 were also suppressed concurrently with induction of apoptosis in the AC-treated KKU213 CCA cell line. Cyanidin and delphinidin are known to suppress the expression of NF- $\kappa \mathrm{B}$ and $\mathrm{Bcl}-2(46,47)$. Furthermore, the turmeric extract in $\mathrm{AC}$ was also identified to suppress NF- $\mathrm{KB}$ and Bcl-2 $(48,49)$. Therefore, we hypothesized that cyanidin, delphinidin and turmeric extract in AC may synergistically inhibit NF- $\kappa \mathrm{B}$ and Bcl-2. Curcumin, an important active ingredient in turmeric extract, is able to inhibit NF- $\mathrm{KB}$ expression and induce cancer cell apoptosis. AC, composed of purple corn cob, blue butterfly pea and turmeric extracts at a ratio of 7:2:1, contains $\sim 60 \mu \mathrm{g}$ turmeric extract per $600 \mu \mathrm{g} / \mathrm{ml} \mathrm{AC}$. In its standard form, turmeric contains $5 \%$ curcumin, implying that there is $\sim 3 \mu \mathrm{g}$ or $8 \mu \mathrm{M}$ curcumin in $60 \mu \mathrm{g}$ turmeric extract. In our previous study, we identified that significant suppression of proliferation, induction of apoptosis ( $4 \%$ of the cell population compared with the untreated control) and suppression of prosurvival proteins in the KKU213 cell line were only observed when treated with $50 \mu \mathrm{M}$ curcumin (49). The synergistic effect of combining different anthocyanins was also demonstrated previously $(50,51)$. These results support our hypothesis that the cytotoxicity of AC against CCA cells is mediated by synergism of cyanidin, delphinidin and turmeric extract. Notably, in the present study, the function of $\mathrm{p} 65$ on AC treatment of KKU213 cells was also determined using p65 plasmid DNA transfection coupled with a clonogenic assay. Although p65 was successfully induced in KKU213 cells, the clonogenic assay revealed that 
A
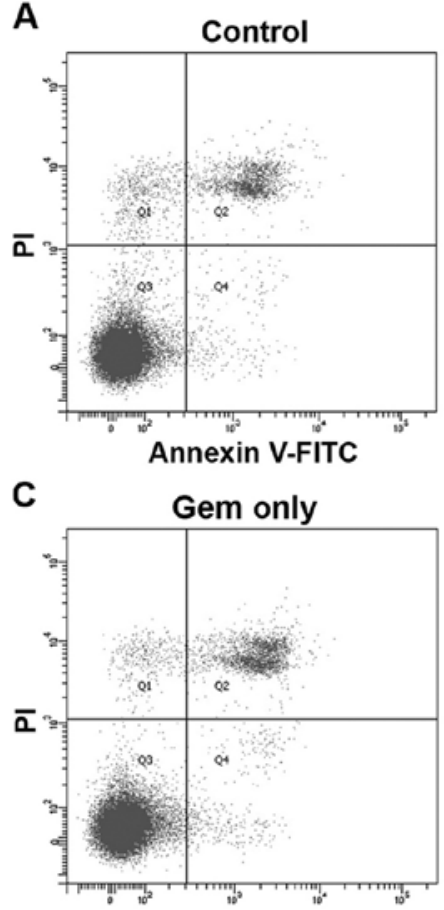

B

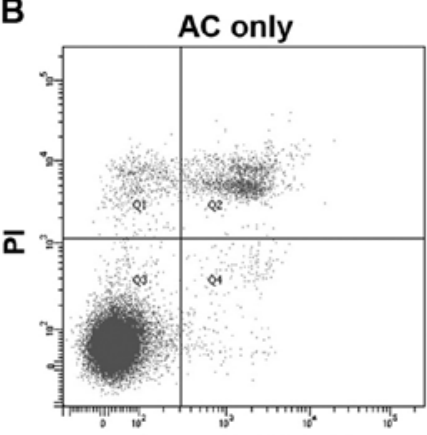

Annexin V-FITC

D

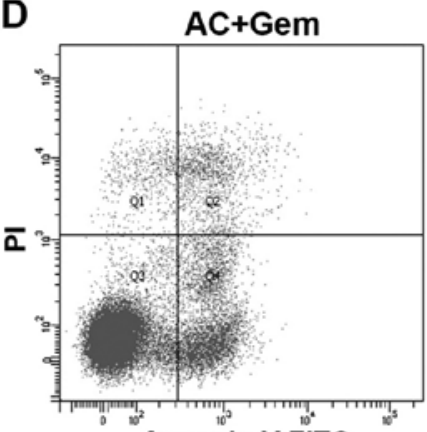

E

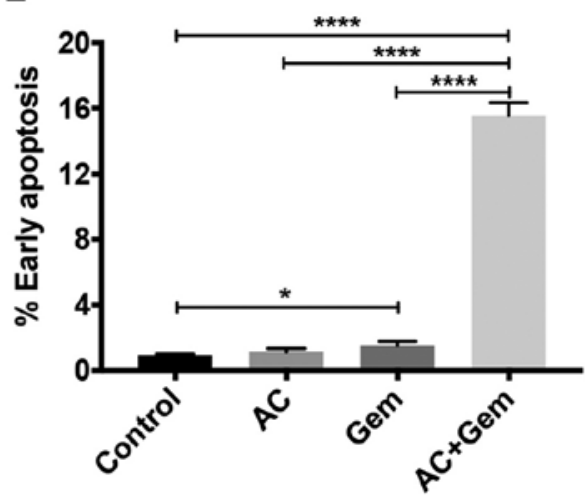

Figure 9. Combination of AC and gemcitabine treatment induces early apoptosis of the KKU214 ${ }^{\mathrm{GemR}}$ cell line. KKU214 ${ }^{\mathrm{GemR}}$ cells were treated with (A) $0.1 \%$ dimethyl sulfoxide, (B) AC ( $300 \mu \mathrm{g} / \mathrm{ml})$ or (C) gemcitabine $(40 \mu \mathrm{M})$, or (D) a combination of AC ( $300 \mu \mathrm{g} / \mathrm{ml})$ and gemcitabine $(40 \mu \mathrm{M})$ for $72 \mathrm{~h}$. Apoptotic cells were stained with Annexin V-FITC/PI solution and analyzed using flow cytometry. (E) The percentage of cells undergoing early apoptosis was calculated from three independent experiments. ${ }^{*} \mathrm{P}<0.05$ and ${ }^{* * * * *} \mathrm{P}<0.0001$. AC, anthocyanin complex; FITC, fluorescein isothiocyanate; PI, propidium iodide; Gem, gemcitabine.

\section{Anthocyanin complex}

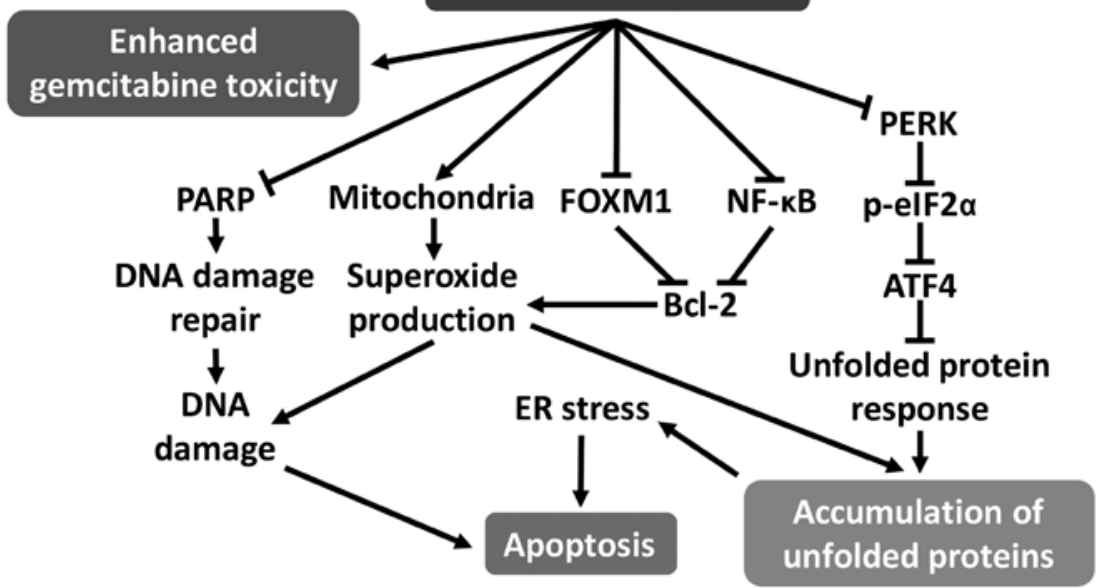

Figure 10. Schematic diagram of the postulated mechanism of AC against CCA cell lines. AC treatment downregulates FOXM1 and NF- $\kappa$ B expression, leading to suppression of Bcl-2 expression. AC treatment also stimulates superoxide production from mitochondria, in part due to Bcl-2 suppression, since this protein serves a function in inhibiting superoxide production from mitochondria. Massive superoxide production leads to DNA damage. Inhibition of the DNA damage-repair protein PARP by AC treatment may induce DNA damage-mediated apoptosis. In addition to DNA damage, superoxide production may result in the induction of protein misfolding or of unfolded proteins, accumulation of which stimulates the UPR in the ER. AC treatment inhibits the primary UPR pathway (PERK/eIF2 $\alpha /$ ATF4), leading to ER stress and induction of apoptosis. AC, anthocyanin complex; CCA, cholangiocarcinoma; FOXM1, forkhead box M1; NF- $\kappa$ B, nuclear factor- $\kappa \mathrm{B}$; Bcl-2, B-cell lymphoma-2; PARP, poly(ADP-ribose) polymerase; UPR, unfolded protein response; ER, endoplasmic reticulum; PERK, protein kinase RNA-like ER kinase; eIF2 $\alpha$, eukaryotic initiation factor $2 \alpha$; ATF4, activating transcription factor 4.

induction of pro-survival transcription factor expression was not able to protect KKU213 cells from apoptosis following AC treatment. Failure of NF- $\kappa \mathrm{B}$ to prevent cell death has also been demonstrated in tumor necrosis factor $\alpha$-induced apoptosis in the HeLa cell line (52). Furthermore, failure to escape apoptosis following p65 induction may be because AC treatment induces
CCA cell apoptosis through multiple pathways. Therefore, AC is a potent apoptosis inducer against CCA cells.

AC treatment also markedly induced superoxide production from mitochondria in KKU213 cells. Mitochondrial superoxide has been demonstrated as an inducer of apoptosis (32). Apoptosis induced in this manner is consistent with a previous 
study demonstrating that diphenyleneiodonium induces mitochondrial superoxide-mediated apoptosis (53). Notably, in the present study, cleaved PARP (data not shown) and cleaved caspase-3 were not observed after $24 \mathrm{~h}$ of $\mathrm{AC}$ treatment in CCA cell lines, suggesting that caspase-independent cell death occurred without activating $\mathrm{Bcl}-2$-associated $\mathrm{X}$ protein, cytochrome $c$ and caspase-3 (54). Caspase-independent cell death was also indicated by treatment with a combination of $\mathrm{AC}$ and pan-caspase inhibitor (Q-VD-OPh): addition of Q-VD-OPh was not able to protect CCA cells from AC-mediated cell death. The defects in the caspase activation pathway are common in cancer, leading to resistance to certain pro-apoptotic stimuli (55). Therefore, triggering caspase-independent cell death is one of the novel approaches to treat cancer (56). Therefore, in addition to CCA, the AC may be useful for the treatment of cancer, particularly that with the ability to evade caspase-dependent cell death. Decreasing PARP expression in CCA cell lines was observed following AC treatment. This result may be explained by the fact that this protein is involved in DNA damage repair (57). Induction of mitochondrial superoxide production was able to induce DNA damage $(58,59)$, suggesting that decreasing of PARP expression after AC treatment could lead to a decrease in DNA damage repair by PARP. Therefore, we hypothesize that AC-treated cells underwent apoptosis via DNA damage-induced caspase-independent cell death (60).

Superoxide in mitochondria may be converted into $\mathrm{H}_{2} \mathrm{O}_{2}$ and diffuse into the cytoplasm. $\mathrm{H}_{2} \mathrm{O}_{2}$ may be catalyzed further to form other highly reactive oxygen species (ROS). Under basal physiological conditions, ROS accumulation may be prevented by cellular antioxidant defense mechanisms (61). However, excessive ROS production caused by excessive mitochondrial superoxide production triggers disturbance of ER redox homeostasis, thus aggravating the accumulation of misfolded or unfolded proteins in the ER or ER stress (62). The process known as the unfolded protein response (UPR) is thus activated to restore ER homeostasis (63). However, if ER stress is severe or prolonged, it may induce cell death (64). The PERK/eIF2 $\alpha / A T F 4$ axis is important in UPR signaling during ER stress (65). PERK activates the phosphorylation of eIF2 $\alpha$ at $\mathrm{Ser}^{51}$, resulting in global translation inhibition (66), but induces the expression of ATF4 (67) to overcome ER stress. The results of the present study identified downregulation of PERK/eIF2 $\alpha / A T F 4$ in an AC-treated CCA cell line. Therefore, we hypothesize that AC treatment induces ER stress and eventual cell death via the stimulation of mitochondrial superoxide production and suppression of PERK/eIF2 $\alpha /$ ATF4 axis-mediated UPR. This hypothesis is supported by previous studies demonstrating that inhibition of PERK or eIF2 $\alpha$ rendered cells susceptible to ER stress-mediated cell death (68-70). Furthermore, a recent study has demonstrated that activation of PERK and eIF2 $\alpha$ was inhibited in cyanidin-treated cells (71).

Drug resistance is a major barrier for chemotherapy in a number of types of cancer, including CCA. Enhancement of chemotherapeutic drug treatment and chemosensitization of cancer cells by plant polyphenols have been the focus of much work and discussion (72). In the present study, the effect of co-treatment of $\mathrm{AC}$ and gemcitabine against a gemcitabine-resistant KKU214 ${ }^{\mathrm{GemR}}$ cell line was investigated.
It was identified that KKU214 ${ }^{\mathrm{GemR}}$ cells were $\sim 80$-fold more resistant to gemcitabine compared with its parental cell line. However, the combination of AC with gemcitabine significantly enhanced the efficacy of gemcitabine against KKU214 ${ }^{\mathrm{GemR}}$ cells compared with single agent treatment. Although the potential of AC against a CCA cell line as well as its potential as a chemosensitizer in a gemcitabine-resistant CCA cell line have been demonstrated in the present study, these results have not been verified in an animal model of CCA. Therefore, the anticancer activity of $\mathrm{AC}$ should be investigated further in xenograft mouse or liver fluke-induced hamster CCA models. Furthermore, the anticancer potential of $\mathrm{AC}$ requires testing in diverse cancer cell types to support its potential use as an alternative or supplementary treatment for cancer, particularly CCA. Additionally, high-throughput approaches, including RNA sequencing, are required to explore the precise mechanisms underlying anticancer and chemosensitization activities of AC.

In conclusion, the results of the present study demonstrated that AC possesses cytotoxicity against CCA cell lines by suppression of cell proliferation and induction of caspase-independent apoptosis possibly via downregulation of FOXM1, NF- $\kappa \mathrm{B}$ and the ER stress response, and by induction of mitochondrial superoxide production. AC also sensitizes KKU214 ${ }^{\mathrm{GemR}}$ cells to gemcitabine treatment. Therefore, AC has potential as an alternative treatment agent and may assist in overcoming drug resistance of CCA when co-administered with other chemotherapeutic agents.

\section{Acknowledgements}

The authors thank Miss Sucharat Limsitthichaikoon for assisting with AC preparation and the Research Instrument Unit, Faculty of Medicine, Khon Kaen University, Khon Kaen, Thailand, for technical and facility support.

\section{Funding}

This study was supported in part by the Thailand Research Fund (TRF) and Khon Kaen University through Royal Golden Jubilee $\mathrm{PhD}$ joint funding program (grant no. PHD/0166/2553) and also by the TRF and Medical Research Council (MRC) UK via TRF-MRC Joint Health Research (grant no. DBG5980004) and Khon Kaen University Research Fund (grant no. KKU600701).

\section{Availability of data and materials}

The data sets generated during the study are available from the corresponding author on reasonable request.

\section{Authors' contributions}

SP and KI mainly designed, performed the research and wrote the manuscript. KI analyzed the data, and AP, CP, CH, KV and PP helped to prepare and provided materials, and analyzed the data. All authors have read and approved the final version of the manuscript.

\section{Ethics approval and consent to participate}

Not applicable. 


\section{Consent for publication}

Not applicable.

\section{Competing interests}

The authors declare that they have no competing interests.

\section{References}

1. Banales JM, Cardinale V, Carpino G, Marzioni M, Andersen JB, Invernizzi P, Lind GE, Folseraas T, Forbes SJ, Fouassier L, et al: Expert consensus document: Cholangiocarcinoma: Current knowledge and future perspectives consensus statement from the European Network for the Study of Cholangiocarcinoma (ENS-CCA). Nat Rev Gastroenterol Hepatol 13: 261-280, 2016.

2. Kirstein MM and Vogel A: Epidemiology and risk factors of cholangiocarcinoma. Visc Med 32: 395-400, 2016.

3. Sripa B and Pairojkul C: Cholangiocarcinoma: Lessons from Thailand. Curr Opin Gastroenterol 24: 349-356, 2008.

4. IARC: A Review of Human Carcinogens: Opisthorchis viverrini and Clonorchis sinensis. IARC Monogr Eval Carcinog Risks Hum 100B: 341-370, 2012.

5. Sripa B, Brindley PJ, Mulvenna J, Laha T, Smout MJ, Mairiang E, Bethony JM and Loukas A: The tumorigenic liver fluke Opisthorchis viverrini - multiple pathways to cancer. Trends Parasitol 28: 395-407, 2012.

6. Prakobwong S, Pinlaor S, Yongvanit P, Sithithaworn P, Pairojkul C and Hiraku Y: Time profiles of the expression of metalloproteinases, tissue inhibitors of metalloproteases cytokines and collagens in hamsters infected with Opisthorchis viverrini with special reference to peribiliary fibrosis and liver injury. Int J Parasitol 39: 825-835, 2009.

7. Loaharanu P and Sornmani S: Preliminary estimates of economic impact of liver fluke infection in Thailand and the feasibility of irradiation as a control measure. Southeast Asian J Trop Med Public Health 22 (Suppl 22): 384-390, 1991.

8. Khan SA, Davidson BR, Goldin R, Pereira SP, Rosenberg WM Taylor-Robinson SD, Thillainayagam AV, Thomas HC, Thursz MR and Wasan H; British Society of Gastroenterology: Guidelines for the diagnosis and treatment of cholangiocarcinoma: Consensus document. Gut 51 (Suppl 6): VI1-VI9, 2002.

9. Anderson CD, Pinson CW, Berlin J and Chari RS: Diagnosis and treatment of cholangiocarcinoma. Oncologist 9: 43-57, 2004.

10. Valle J, Wasan H, Palmer DH, Cunningham D, Anthoney A, Maraveyas A, Madhusudan S, Iveson T, Hughes S, Pereira SP, et al; ABC-02 Trial Investigators: Cisplatin plus gemcitabine versus gemcitabine for biliary tract cancer. N Engl J Med 362: 1273-1281, 2010

11. Surh YJ: Cancer chemoprevention with dietary phytochemicals. Nat Rev Cancer 3: 768-780, 2003.

12. Wang H, Khor TO, Shu L, Su ZY, Fuentes F, Lee JH and Kong AN: Plants vs. cancer: A review on natural phytochemicals in preventing and treating cancers and their druggability. Anticancer Agents Med Chem 12: 1281-1305, 2012.

13. Singh CK, Siddiqui IA, El-Abd S, Mukhtar H and Ahmad N Combination chemoprevention with grape antioxidants. Mol Nutr Food Res 60: 1406-1415, 2016.

14. Castañeda-Ovando A, Pacheco-Hernández ML, PáezHernández ME, Rodríguez JA and Galán-Vidal CA Pacheco-Hernández MdL, Páez-Hernández ME, Rodríguez JA and Galán-Vidal CA: Chemical studies of anthocyanins: A review. Food Chem 113: 859-871, 2009.

15. Cerletti C, De Curtis A, Bracone F, Digesù C, Morganti AG, Iacoviello L, de Gaetano G and Donati MB: Dietary anthocyanins and health: Data from FLORA and ATHENA EU projects. Br J Clin Pharmacol 83: 103-106, 2017.

16. Lin BW, Gong CC, Song HF and Cui YY: Effects of anthocyanins on the prevention and treatment of cancer. Br J Pharmacol 174 1226-1243, 2017.

17. Li D, Wang P, Luo Y, Zhao M and Chen F: Health benefits of anthocyanins and molecular mechanisms: Update from recent decade. Crit Rev Food Sci Nutr 57: 1729-1741, 2017.

18. Yousuf B, Gul K, Wani AA and Singh P: Health benefits of anthocyanins and their encapsulation for potential use in food systems: A Review. Crit Rev Food Sci Nutr 56: 2223-2230, 2016.
19. Nichenametla SN, Taruscio TG, Barney DL and Exon JH: A review of the effects and mechanisms of polyphenolics in cancer. Crit Rev Food Sci Nutr 46: 161-183, 2006.

20. Umar Lule S and Xia W: Food phenolics, pros and cons: A Review. Food Rev Int 21: 367-388, 2005

21. Wang LS and Stoner GD: Anthocyanins and their role in cancer prevention. Cancer Lett 269: 281-290, 2008.

22. Yang X, Luo E, Liu X, Han B, Yu X and Peng X: Delphinidin3-glucoside suppresses breast carcinogenesis by inactivating the Akt/HOTAIR signaling pathway. BMC Cancer 16: 423, 2016.

23. Chen PN, Chu SC, Chiou HL, Kuo WH, Chiang CL and Hsieh YS: Mulberry anthocyanins, cyanidin 3-rutinoside and cyanidin 3-glucoside, exhibited an inhibitory effect on the migration and invasion of a human lung cancer cell line. Cancer Lett 235: 248-259, 2006.

24. Kamei H, Kojima T, Hasegawa M, Koide T, Umeda T, Yukawa T and Terabe K: Suppression of tumor cell growth by anthocyanins in vitro. Cancer Invest 13: 590-594, 1995.

25. Eiro MJ and Heinonen M: Anthocyanin color behavior and stability during storage: Effect of intermolecular copigmentation. J Agric Food Chem 50: 7461-7466, 2002.

26. Intuyod K, Priprem A, Limphirat W, Charoensuk L, Pinlaor P, Pairojkul C, Lertrat K and Pinlaor S: Anti-inflammatory and anti-periductal fibrosis effects of an anthocyanin complex in Opisthorchis viverrini-infected hamsters. Food Chem Toxicol 74: 206-215, 2014

27. Tepsiri N, Chaturat L, Sripa B, Namwat W, Wongkham S, Bhudhisawasdi V and Tassaneeyakul W: Drug sensitivity and drug resistance profiles of human intrahepatic cholangiocarcinoma cell lines. World J Gastroenterol 11: 2748-2753, 2005.

28. Wattanawongdon W, Hahnvajanawong C, Namwat N, Kanchanawat S, Boonmars T, Jearanaikoon P, Leelayuwat C, Techasen A and Seubwai W: Establishment and characterization of gemcitabine-resistant human cholangiocarcinoma cell lines with multidrug resistance and enhanced invasiveness. Int J Oncol 47: 398-410, 2015.

29. Kuželová K, Grebeňová D and Brodská B: Dose-dependent effects of the caspase inhibitor Q-VD-OPh on different apoptosis-related processes. J Cell Biochem 112: 3334-3342, 2011.

30. Franken NA, Rodermond HM, Stap J, Haveman J and van Bree C: Clonogenic assay of cells in vitro. Nat Protoc 1: 2315-2319, 2006.

31. Puck TT and Marcus PI: Action of x-rays on mammalian cells. J Exp Med 103: 653-666, 1956.

32. Cai J and Jones DP: Superoxide in apoptosis. Mitochondrial generation triggered by cytochrome $c$ loss. J Biol Chem 273 11401-11404, 1998

33. Piva R, Belardo G and Santoro MG: NF-kappaB: A stressregulated switch for cell survival. Antioxid Redox Signal 8: 478-486, 2006

34. Myatt SS and Lam EW: The emerging roles of forkhead box (Fox) proteins in cancer. Nat Rev Cancer 7: 847-859, 2007.

35. Cao SS and Kaufman RJ: Endoplasmic reticulum stress and oxidative stress in cell fate decision and human disease. Antioxid Redox Signal 21: 396-413, 2014.

36. Holohan C, Van Schaeybroeck S, Longley DB and Johnston PG: Cancer drug resistance: An evolving paradigm. Nat Rev Cancer 13: 714-726, 2013.

37. Longo L, Platini F, Scardino A, Alabiso O, Vasapollo G and Tessitore L: Autophagy inhibition enhances anthocyanininduced apoptosis in hepatocellular carcinoma. Mol Cancer Ther 7: 2476-2485, 2008.

38. Neto CC, Amoroso JW and Liberty AM: Anticancer activities of cranberry phytochemicals: An update. Mol Nutr Food Res 52 (Suppl 1): S18-S27, 2008.

39. Rugină D, Hanganu D, Diaconeasa Z, Tăbăran F, Coman C, Leopold L, Bunea A and Pintea A: Antiproliferative and apoptotic potential of cyanidin-based anthocyanins on melanoma cells. Int J Mol Sci 18: 949-959, 2017.

40. Jinawath N, Chamgramol Y, Furukawa Y, Obama K, Tsunoda T, Sripa B, Pairojkul C and Nakamura Y: Comparison of gene expression profiles between Opisthorchis viverrini and non-Opisthorchis viverrini associated human intrahepatic cholangiocarcinoma. Hepatology 44: 1025-1038, 2006.

41. Zhang JR, Lu F, Lu T, Dong WH, Li P, Liu N, Ma DX and Ji CY: Inactivation of FoxM1 transcription factor contributes to curcumin-induced inhibition of survival, angiogenesis, and chemosensitivity in acute myeloid leukemia cells. J Mol Med (Berl) 92: 1319-1330, 2014

42. Karin M: Nuclear factor-kappaB in cancer development and progression. Nature 441: 431-436, 2006 
43. Hoesel B and Schmid JA: The complexity of NF- $\kappa$ B signaling in inflammation and cancer. Mol Cancer 12: 86, 2013.

44. Baldwin AS Jr: The NF-kappa B and I kappa B proteins: New discoveries and insights. Annu Rev Immunol 14: 649-683, 1996.

45. Seubwai W, Wongkham C, Puapairoj A, Khuntikeo N, Pugkhem A, Hahnvajanawong C, Chaiyagool J, Umezawa K, Okada S and Wongkham S: Aberrant expression of NF- $\kappa \mathrm{B}$ in liver fluke associated cholangiocarcinoma: Implications for targeted therapy. PLoS One 9: e106056, 2014.

46. Hafeez BB, Siddiqui IA, Asim M, Malik A, Afaq F, Adhami VM Saleem M, Din M and Mukhtar H: A dietary anthocyanidin delphinidin induces apoptosis of human prostate cancer PC3 cells in vitro and in vivo: Involvement of nuclear factor-kappaB signaling. Cancer Res 68: 8564-8572, 2008.

47. Hecht SS, Huang C, Stoner GD, Li J, Kenney PM, Sturla SJ and Carmella SG: Identification of cyanidin glycosides as constituents of freeze-dried black raspberries which inhibit antibenzo[a]pyrene-7,8-diol-9,10-epoxide induced NFkappaB and AP-1 activity. Carcinogenesis 27: 1617-1626, 2006.

48. Kim JH, Gupta SC, Park B, Yadav VR and Aggarwal BB: Turmeric (Curcuma longa) inhibits inflammatory nuclear factor $(\mathrm{NF})-\kappa \mathrm{B}$ and NF- $\mathrm{KB}$-regulated gene products and induces death receptors leading to suppressed proliferation, induced chemosensitization, and suppressed osteoclastogenesis. Mol Nutr Food Res 56: 454-465, 2012.

49. Prakobwong S, Gupta SC, Kim JH, Sung B, Pinlaor P, Hiraku Y, Wongkham S, Sripa B, Pinlaor S and Aggarwal BB: Curcumin suppresses proliferation and induces apoptosis in human biliary cancer cells through modulation of multiple cell signaling pathways. Carcinogenesis 32: 1372-1380, 2011.

50. Rahman MM, Ichiyanagi T, Komiyama T, Hatano $\mathrm{Y}$ and Konishi T: Superoxide radical- and peroxynitrite-scavenging activity of anthocyanins; structure-activity relationship and their synergism. Free Radic Res 40: 993-1002, 2006.

51. Kausar H, Jeyabalan J, Aqil F, Chabba D, Sidana J, Singh IP and Gupta RC: Berry anthocyanidins synergistically suppress growth and invasive potential of human non-small-cell lung cancer cells. Cancer Lett 325: 54-62, 2012.

52. Casanelles E, Gozzelino R, Marqués-Fernández $F$, Iglesias-Guimarais V, Garcia-Belinchón M, Sánchez-Osuna M, Solé C, Moubarak RS, Comella JX and Yuste VJ: NF-kB activation fails to protect cells to TNF $\alpha$-induced apoptosis in the absence of Bcl-xL, but not Mcl-1, Bcl-2 or Bcl-w. Biochim Biophys Acta 1833 1085-1095, 2013.

53. Li N, Ragheb K, Lawler G, Sturgis J, Rajwa B, Melendez JA and Robinson JP: DPI induces mitochondrial superoxide-mediated apoptosis. Free Radic Biol Med 34: 465-477, 2003.

54. Kondo K, Obitsu S, Ohta S, Matsunami K, Otsuka $\mathrm{H}$ and Teshima R: Poly(ADP-ribose) polymerase (PARP)-1-independent apoptosis-inducing factor (AIF) release and cell death are induced by eleostearic acid and blocked by alpha-tocopherol and MEK inhibition. J Biol Chem 285: 13079-13091, 2010.
55. Fernald $\mathrm{K}$ and Kurokawa $\mathrm{M}$ : Evading apoptosis in cancer. Trends Cell Biol 23: 620-633, 2013.

56. Mathiasen IS and Jäättelä M: Triggering caspase-independent cell death to combat cancer. Trends Mol Med 8: 212-220, 2002.

57. Herceg Z and Wang ZQ: Functions of poly(ADP-ribose) polymerase (PARP) in DNA repair, genomic integrity and cell death. Mutat Res 477: 97-110, 2001.

58. Schieber M and Chandel NS: ROS function in redox signaling and oxidative stress. Curr Biol 24: R453-R462, 2014.

59. Dizdaroglu M, Jaruga P, Birincioglu M and Rodriguez H: Free radical-induced damage to DNA: Mechanisms and measurement. Free Radic Biol Med 32: 1102-1115, 2002.

60. Borges HL, Linden R and Wang JY: DNA damage-induced cell death: Lessons from the central nervous system. Cell Res 18: 17-26, 2008.

61. Murphy MP: How mitochondria produce reactive oxygen species. Biochem J 417: 1-13, 2009.

62. Higa A and Chevet E: Redox signaling loops in the unfolded protein response. Cell Signal 24: 1548-1555, 2012.

63. Schröder M and Kaufman RJ: ER stress and the unfolded protein response. Mutat Res 569: 29-63, 2005.

64. Xu C, Bailly-Maitre B and Reed JC: Endoplasmic reticulum stress: Cell life and death decisions. J Clin Invest 115: 2656-2664, 2005.

65. Ron D: Translational control in the endoplasmic reticulum stress response. J Clin Invest 110: 1383-1388, 2002.

66. Shi Y, Vattem KM, Sood R, An J, Liang J, Stramm L and Wek RC: Identification and characterization of pancreatic eukaryotic initiation factor 2 alpha-subunit kinase, PEK, involved in translational control. Mol Cell Biol 18: 7499-7509, 1998.

67. Harding HP, Novoa I, Zhang Y, Zeng H, Wek R, Schapira M and Ron D: Regulated translation initiation controls stress-induced gene expression in mammalian cells. Mol Cell 6: 1099-1108, 2000.

68. Scheuner D, Song B, McEwen E, Liu C, Laybutt R, Gillespie P, Saunders T, Bonner-Weir S and Kaufman RJ: Translational control is required for the unfolded protein response and in vivo glucose homeostasis. Mol Cell 7: 1165-1176, 2001.

69. Harding HP, Zhang Y, Bertolotti A, Zeng H and Ron D: Perk is essential for translational regulation and cell survival during the unfolded protein response. Mol Cell 5: 897-904, 2000.

70. Rajesh K, Krishnamoorthy J, Kazimierczak U, Tenkerian C, Papadakis AI, Wang S, Huang S and Koromilas AE: Phosphorylation of the translation initiation factor eIF $2 \alpha$ at serine 51 determines the cell fate decisions of Akt in response to oxidative stress. Cell Death Dis 6: e1591, 2015.

71. Thummayot S, Tocharus C, Suksamrarn A and Tocharus J: Neuroprotective effects of cyanidin against A $\beta$-induced oxidative and ER stress in SK-N-SH cells. Neurochem Int 101: 15-21, 2016.

72. Garg AK, Buchholz TA and Aggarwal BB: Chemosensitization and radiosensitization of tumors by plant polyphenols. Antioxid Redox Signal 7: 1630-1647, 2005. 